\title{
Tropospheric temperature response to stratospheric ozone recovery in the 21st century
}

\author{
Y. $\mathrm{Hu}^{1}$, Y. Xia ${ }^{1}$, and Q. Fu ${ }^{2,3}$ \\ ${ }^{1}$ Laboratory for Climate and Ocean-Atmosphere Studies, Dept. of Atmospheric and Oceanic Sciences, School of Physics, \\ Peking University, Beijing, 100871, China \\ ${ }^{2}$ Dept. of Atmospheric Sciences, University of Washington, Seattle, WA, 98195-1640, USA \\ ${ }^{3}$ College of Atmospheric Sciences, Lanzhou University, Lanzhou, 730000, China
}

Received: 26 July 2010 - Published in Atmos. Chem. Phys. Discuss.: 22 September 2010

Revised: 10 June 2011 - Accepted: 28 June 2011 - Published: 2 August 2011

\begin{abstract}
Recent simulations predicted that the stratospheric ozone layer will likely return to pre-1980 levels in the middle of the 21st century, as a result of the decline of ozone depleting substances under the Montreal Protocol. Since the ozone layer is an important component in determining stratospheric and tropospheric-surface energy balance, the recovery of stratospheric ozone may have significant impact on tropospheric-surface climate. Here, using multi-model results from both the Intergovernmental Panel on Climate Change Fourth Assessment Report (IPCC-AR4) models and coupled chemistry-climate models, we show that as ozone recovery is considered, the troposphere is warmed more than that without considering ozone recovery, suggesting an enhancement of tropospheric warming due to ozone recovery. It is found that the enhanced tropospheric warming is mostly significant in the upper troposphere, with a global and annual mean magnitude of $\sim 0.41 \mathrm{~K}$ for $2001-2050$. We also find that relatively large enhanced warming occurs in the extratropics and polar regions in summer and autumn in both hemispheres, while the enhanced warming is stronger in the Northern Hemisphere than in the Southern Hemisphere. Enhanced warming is also found at the surface. The global and annual mean enhancement of surface warming is about $0.16 \mathrm{~K}$ for $2001-2050$, with maximum enhancement in the winter Arctic.
\end{abstract}

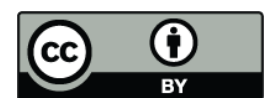

Correspondence to: $\mathrm{Y} . \mathrm{Hu}$

(yyhu@pku.edu.cn)

\section{Introduction}

After about $20 \mathrm{yr}$ of severe depletion from the late 1970s to late 1990s (Solomon, 1999), the stratospheric ozone layer shows a stabilization or a weak increase in the past decade, consistent with the observed decline in ozone depleting substances (ODSs) that peaked in the middle 1990s (Weatherhead and Andersen, 2006; WMO, 2007). Since ODSs are also greenhouse gases, the reduction of ODSs under the 1987 Montreal Protocol serves to protect both the ozone layer and climate (Velders et al., 2007). Coupled chemistry-climate model (CCM) simulations, with projected stratospheric chlorine loading, predicted that stratospheric ozone will return to pre-1980 levels around 2050 and may even be above pre-1980 levels by 2100 (Weatherhead and Andersen, 2006; WMO, 2007; Eyring et al., 2007; Chipperfield, 2009). The recovery of the ozone layer will not only help reduce ultraviolet transmission, which benefits ecosystems on the Earth's surface, but also have important impacts on troposphere and surface climate throughout its radiative effect.

The radiative effect of the ozone layer is an important component in determining the energy balance in the troposphere and surface (Ramanathan and Dickinson, 1979). While ozone warms the stratosphere by absorbing solar radiation and thermal infrared radiation emitted from the troposphere and surface, its emission in the $9.6 \mu \mathrm{m}$ band cools the stratosphere, but warms the troposphere. Because the ozone layer absorbs more radiative energy than it emits, an increase (decrease) of stratospheric ozone increases (decreases) stratospheric temperatures, and also increases (decreases) the downward infrared radiation to the troposphere, causing tropospheric warming (cooling) (Ramanathan and

Published by Copernicus Publications on behalf of the European Geosciences Union. 
Dickinson, 1979). Using a radiative-convective model, Ramanathan and Dickinson (1979) showed that $~ 50 \%$ downward infrared radiation from stratospheric ozone is absorbed by tropospheric high clouds and the remaining $50 \%$ is largely absorbed by the surface. But most of downward infrared radiation from other stratospheric greenhouse gases such as $\mathrm{CO}_{2}$ is absorbed in the upper troposphere. Note that an increase of stratospheric ozone decreases the downward solar radiation reaching to the troposphere and surface, which partly counteracts the thermal infrared radiation effects on the tropospheric temperatures.

The radiative forcing of ozone layer changes, especially stratospheric ozone depletion in the last $20 \mathrm{yr}$ of the 20th century, and its impact on troposphere-surface temperatures had been investigated using radiation transfer models (Wang et al., 1980; Lacis et al., 1990; Wang, et al., 1993; Forster and Shine, 1997), the general circulation model (GCM) (Ramaswamy et al., 1992) and satellite observations (Molnar et al., 1994). All these studies indicated that stratospheric ozone depletion caused a significant negative radiative forcing on the troposphere, which may have offset up to $30 \%$ of the positive forcing due to increasing well-mixed greenhouse gases between the late 1970s and the late 1990s. In a more recent study, Cordero and Forster (2006) showed that GCMs with stratospheric ozone depletion yielded weaker warming trends compared with GCMs without ozone depletion in IPCC-AR4 20th century simulations. They showed that the difference of warming trends in the upper troposphere is about $0.4 \mathrm{~K}$ over $1950-1999$ and $0.1 \mathrm{~K}$ over 1979-1999.

Because of the latitudinal dependence of the ozone layer changes in the stratosphere, ozone would cause changes in latitudinal thermal structures in the troposphere (Ramanathan and Dickinson, 1979). Studies in the past decade have demonstrated evidence that ozone depletion had caused changes in tropospheric circulations and wave activity (Hartmann et al., 2000; Thompson and Solomon, 2002; Hu and Tung, 2003; Chen and Held, 2007). It was shown that stratospheric ozone depletion from the late 1970s to the late 1990s had caused stratospheric polar cooling and, thus, accelerated westerly winds and decreased wave activity at middle and high latitudes. The accelerated westerly winds near the surface consequently caused surface warming over the Antarctic Peninsula (Thompson and Solomon, 2002) and EuropeanAsian continental regions (Hartmann et al., 2002; Thompson and Wallace, 2001; Hu et al., 2005). Polvani et al. (2010) showed that stratospheric ozone depletion played a major role in causing observed poleward expansion of the Hadley circulation in the past few decades (Fu et al., 2006; Hu and Fu, 2007; Seidel et al., 2008).

On the other hand, a positive radiative forcing associated with ozone recovery is expected in the 21 st century, and that the changes in atmospheric circulations, mentioned above, will be reversed. Using a coupled chemistry-climate model (CCM), Perlwitz et al. (2008) have shown that the recovery of the Antarctic ozone hole will lead to a trend toward the neg- ative polarity of the southern annular mode (SAM) in austral summer, and that the negative SAM trend forced by ozone recovery dominates and opposes that induced by increasing greenhouse gases. Based on the multi-model ensemble comparison of IPCC-AR4 GCM results for the 21st century and CCM results, Son et al. (2008, 2009a, 2010) have examined the influences of the recovery of the Antarctic ozone hole on Southern-Hemisphere ( $\mathrm{SH}$ ) troposphere-surface climate. They showed nearly the same results as those in Perlwitz et al. (2008).

The main goal of the present study is to demonstrate that ozone recovery may have important impacts on tropospheresurface climate over the globe, not only at Southern Hemisphere (SH) high latitudes. We will show that stratospheric ozone recovery may actually have greater impacts on tropospheric climate in the Northern Hemisphere (NH) than in SH. We will focus on tropospheric temperature response to the radiative forcing associated with ozone recovery by comparing temperature trends from three groups of simulations for the 21st century. The model data used here is described in Sect. 2. Results will be presented in Sect. 3. Discussion and conclusions are summarized in Sect. 4.

\section{Simulation data and methods}

The data used in this study are from IPCC-AR4 simulations for the 21st century with the A1B scenario for greenhouse gases (IPCC, 2007) and simulations from the first version of CCM validation (CCMVal-1) models for the Stratospheric Processes And their Role in Climate project (SPARC) (Eyring et al., 2006). The IPCC-AR4 models are separated into 2 groups, depending on whether a model has prescribed ozone recovery (see Table 1). Therefore, there are three groups of models: 11 IPCC-AR4 models without ozone recovery, 10 IPCC-AR4 models with prescribed ozone recovery and 8 CCMVal-1 models (Table 2). Hereafter, the three groups of models are denoted as AR4-NO-O 3 , AR4$\mathrm{O}_{3}$ and CCMVal-1, respectively. In temperature trend calculations, all available ensemble members are used for each model.

The prescribed ozone recovery in AR4- $\mathrm{O}_{3}$ models is either considered as a linear function of time or from the predictions of two-dimensional models which are forced by halogen loading, based on the Montreal Protocol (Meehl et al., 2007). However, it is worth noting that details of prescribed ozone are not well documented. CCMVal-1 models are all integrated up to the year 2050 and are forced with the IPCC A1B scenario for greenhouse gases, Ab scenario for halogen concentrations and prescribed sea surface temperatures (SST) from their own AR4 coupled atmosphere-ocean model simulations that have prescribed ozone recovery, except for MRI which is forced with SSTs from coupled simulations without including prescribed ozone recovery (Eyring et al., 2006). In contrast to AR4 models, CCMVal-1 models have 
Table 1. IPCC-AR4 models used in this study. "Y" and " $\mathrm{N}$ " in brackets denote the model has or has not prescribed ozone recovery, respectively. Numbers indicate ensemble numbers of simulations.

\begin{tabular}{lcc}
\hline Model Name & 20C3M & A1B \\
\hline CSIRO MK3.0 & $2(\mathrm{Y})$ & \\
CSIROMK3.5 & $3(\mathrm{Y})$ & $1(\mathrm{Y})$ \\
GFDL CM2.0 & $3(\mathrm{Y})$ & $1(\mathrm{Y})$ \\
GFDL CM2.1 & $3(\mathrm{Y})$ & $1(\mathrm{Y})$ \\
INGV SXG & $1(\mathrm{Y})$ & $1(\mathrm{Y})$ \\
MIROC3.2 hires & $1(\mathrm{Y})$ & $1(\mathrm{Y})$ \\
MIROC3.2 medres & $3(\mathrm{Y})$ & $3(\mathrm{Y})$ \\
MPI ECHAM5/MPI-OM & $4(\mathrm{Y})$ & $4(\mathrm{Y})$ \\
NCAR CCSM3.0 & $8(\mathrm{Y})$ & $7(\mathrm{Y})$ \\
NCAR PCM1 & $4(\mathrm{Y})$ & \\
UKMO HadCM3 & $2(\mathrm{Y})$ & $1(\mathrm{Y})$ \\
UKMO HadGEM1 & $2(\mathrm{Y})$ & $1(\mathrm{Y})$ \\
GISS EH & $5(\mathrm{Y})$ & $3(\mathrm{~N})$ \\
GISS ER & $9(\mathrm{Y})$ & $5(\mathrm{~N})$ \\
BCCR BCM2.0 & $1(\mathrm{~N})$ & $1(\mathrm{~N})$ \\
CCCMa CGCM3.1 T47 & $5(\mathrm{~N})$ & $5(\mathrm{~N})$ \\
CCCma CGCM3.1 T63 & $1(\mathrm{~N})$ & $1(\mathrm{~N})$ \\
CNRM CM3* & $1(\mathrm{~N})$ & $1(\mathrm{~N})$ \\
GISS AOM & $2(\mathrm{~N})$ & $2(\mathrm{~N})$ \\
IAP FGOALS-g1.0 & $3(\mathrm{~N})$ & $3(\mathrm{~N})$ \\
INM CM3.0 & $1(\mathrm{~N})$ & $1(\mathrm{~N})$ \\
IPSL CM4 & $2(\mathrm{~N})$ & $1(\mathrm{~N})$ \\
MRI CGCM2.3.2 & $5(\mathrm{~N})$ & $5(\mathrm{~N})$ \\
\hline
\end{tabular}

fully interactive stratospheric chemistry and well-resolved stratospheres with better parameterizations of gravity-wave drags. Regardless of the details, the major difference in external forcing between AR4-NO-O $\mathrm{O}_{3}$ and other two groups of models is that the latter two include ozone recovery.

Although these models may have different internal processes and simulation performances, previous studies by comparing AR4-O ${ }_{3} / \mathrm{CCMVal}-1$ with AR4-NO-O $\mathrm{O}_{3}$ results showed a consistent result, that is, the recovery of the Antarctic ozone hole causes the weakening of the southern polar night jet and negative trends in SAM (Perlwizt et al., 2008; Son et al., 2008, 2009a, 2010). More importantly, the mean transient climate sensitivity of the $\mathrm{AR} 4-\mathrm{NO}-\mathrm{O}_{3}$ models is the same as that from the $\mathrm{AR} 4-\mathrm{O}_{3}$ models, which is $1.7^{\circ} \mathrm{C}$ (IPCC 2007). Therefore, these simulations offer an opportunity to evaluate tropospheric temperature response to the radiative forcing associated with ozone recovery. Since all CCMVal1 models are forced with the A1B scenario of greenhouse gases, we only use AR4 output with the A1B scenario. Comparison of temperature trends are shown for the period of 2001-2050 because almost all CCMVal-1 models and twodimensional chemistry models predicted that ozone will linearly return to pre-1980 levels around 2050 (Weatherhead and Andersen, 2006; Eyring et al., 2007; WMO, 2007), and ozone recovery in AR4- $\mathrm{O}_{3}$ models is also linearly prescribed
Table 2. CCMVal-1-1 models used in this study. REF1 and REF2 denote simulations for the 20th and 21st century, respectively. Numbers indicate ensemble numbers of simulations.

\begin{tabular}{lcc}
\hline Model Name & REF1 & REF2 \\
\hline AMTRAC & 1 & 1 \\
CCSRNIES & & 1 \\
CMAM & 1 & 3 \\
GEOSCCM & 1 & 1 \\
MRI & & 1 \\
SOCOL & & 1 \\
ULAQ & 1 & 1 \\
WACCM & 3 & 3 \\
\hline
\end{tabular}

over the same period (Meehl et al., 2007). For calculating linear trends in monthly temperatures, we first calculate ensemble average for each model. Then, we calculate ensemble average for each group of models. Linear temperature trends are derived from the ensemble average for each group of models.

For a comparison with results from GCMs, we will also use a radiative-convective model to calculate tropospheresurface temperature responses to ozone increase between 2001 and 2050 following CCMVal-1 models. The radiativeconvective model was developed by the Virtual Planetary Laboratory at the University of Washington. The solar radiation code is from Pavlov et al. (2000), and the thermal infrared radiation is from the rapid radiative transfer model (www.rtweb.aer.com). Details of the radiative-convective model can be found at http://vpl.astro.washington.edu/sci/ AntiModels/models09.html.

\section{Results}

Before we show temperature trends from multimodel ensemble means, let us first evaluate temperature trends for individual models. Figure 1 shows global and annual mean temperature trends at levels from 1000 to $10 \mathrm{hPa}$ from all individual models for AR4 and CCMVal-1 models. In general, AR4 models without ozone recovery have consistently weaker warming trends in the troposphere, while AR4 models with ozone recovery and CCMVal-1 models all show consistently stronger warming trends. It indicates that models with and without ozone recovery have systematic difference in simulating tropospheric temperatures. For AR4 models without ozone recovery, the weakest tropospheric warming trends are from BBCR-BCM2.0. For AR4 models with ozone recovery and CCMVal-1 models, the largest tropospheric warming trends are from MIROC3.2 and ULAQ, respectively.

Figure 2a shows vertical profiles of global annual mean temperature trends over 2001-2050 for the three groups of models. All predict warming in the troposphere and lower 


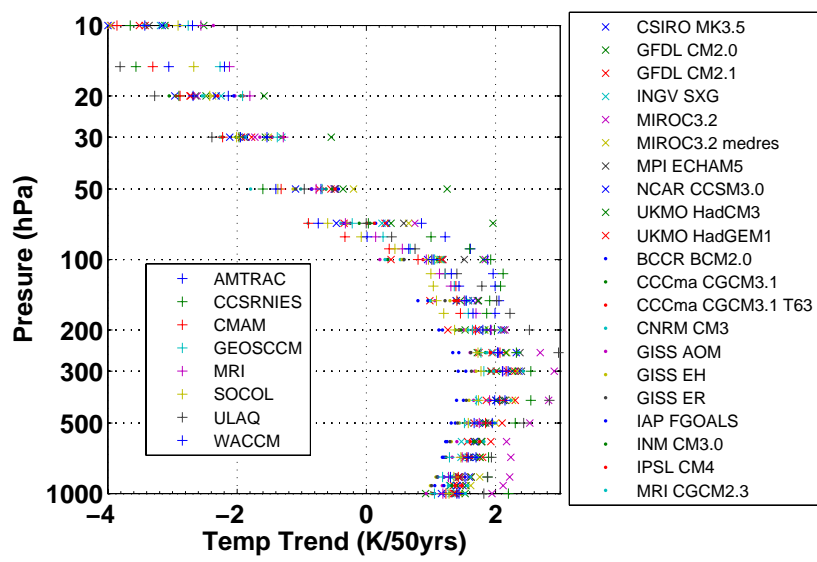

Fig. 1. Global and annual mean temperature trends for AR4 and CCMVal-1 models. Dots: AR4 models without ozone recovery, crosses: AR4 models with ozone recovery, and right-crosses: CCMVal-1 models.

stratosphere, but cooling at higher stratospheric layers. The maximum warming is around $300 \mathrm{hPa}$. The warming is caused by increasing well-mixed greenhouse gases in all models (WMO, 2007; IPCC, 2007) and also partly by stratospheric ozone increase in AR4-O $\mathrm{O}_{3}$ and CCMVal-1 models as addressed below. Figure 2a also demonstrates differences in tropospheric trends between AR4-NO-O 3 models and the other two model groups, which is our key interest in this paper. The warming trends in AR4- $\mathrm{O}_{3}$ and CCMVal-1 models show high consistency in the troposphere and are all greater than that in AR4-NO-O 3 models. The largest difference in tropospheric warming trends is found at about $300 \mathrm{hPa}$, which is about $0.41 \mathrm{~K}$ over the $50 \mathrm{yr}$ between $\mathrm{AR} 4-\mathrm{O}_{3}$ and AR4-NO-O 3 and also between CCMVal-1 and AR4-NO-O $\mathrm{O}_{3}$. It is about one-fifth of the averaged warming trends over all models at $300 \mathrm{hPa}$, which is about $2.0 \mathrm{~K}$ for the $50 \mathrm{yr}$. Student $\mathrm{t}$-test indicates that temperature trend differences among are all statistically significant. Significant levels are all above the $95 \%$ confidence level (t-test values are greater than 2.0). The stronger warming indicates that the tropospheric warming due to the increase of greenhouse gases will be enhanced by stratospheric ozone recovery.

To further illustrate tropospheric temperature responses to the radiative forcing of stratospheric ozone changes, we also calculate temperature trends over the period of 19651999 when the ozone layer was depleted, using the AR4 and CCMVal-1 simulation results for the 20th century. In general, AR4 models with prescribed ozone recovery for 21st century simulations also have prescribed ozone depletion for 20th century simulations. Among AR4 models for 20th century simulations, 14 models have prescribed ozone depletion and 9 models do not (see Table 1). Among the 8 CCMVal1 models, 5 have the 20th century simulations starting from 1960, and the other 3 started from 1980. Thus, data from these 5 CCMVal-1 models are used here (see Table 2).
Temperature trends over 1965-1999 are shown in Fig. 2b. It is evident that both AR4 models with ozone depletion and CCMVal-1 models produced weaker tropospheric warming compared with AR4 models without ozone depletion. The trend difference at $300 \mathrm{hPa}$ between AR4 models with and without ozone depletion is about $-0.26 \mathrm{~K}$ over the $35 \mathrm{yr}$. The trend difference between CCMVal-1 models and AR4 models without ozone depletion is larger, about $-0.36 \mathrm{~K}$ over the 35 yr. Cordero and Forster (2006) showed that the difference in global and annual mean temperature trends between AR4 models with and without ozone depletion is about $-0.4 \mathrm{~K}$ over 1958-1999 and about $-0.1 \mathrm{~K}$ over 1979-1999, respectively. It appears that the enhanced tropospheric warming associated with ozone recovery is comparable to the reduced warming by ozone depletion from the 1960s to the 1990s, but larger than that from the 1980s to the 1990s.

Annual and regional mean temperature trends are plotted in Fig. 3. In all regions, both $\mathrm{AR} 4-\mathrm{O}_{3}$ and CCMVal-1 models display greater tropospheric warming trends compared with AR4-NO-O ${ }_{3}$ models. In particular, trend differences in the Antarctic (Fig. 3a), NH middle latitudes (Fig. 3e), and the Arctic (Fig. 3f) are larger than in other regions. In the Antarctic and NH middle latitudes, CCMVal-1 models shows greater tropospheric warming than that generated by $\mathrm{AR} 4-\mathrm{O}_{3}$ models, while in other regions, the two groups of models have almost the same warming magnitudes. Annual and hemispheric mean temperature trends are plotted in Fig. 4. One can find that tropospheric trend differences are larger in $\mathrm{NH}$ than in $\mathrm{SH}$, and again that the largest differences are at $300 \mathrm{hPa}$. In $\mathrm{NH}$, the largest trend differences at $300 \mathrm{hPa}$ between AR4-O3 and AR4-NO-O3 models and between CCMVal-1 and AR4-NO-O3 models are very close, about $0.47 \mathrm{~K}$ and $0.49 \mathrm{~K}$ over the $50 \mathrm{yr}$, respectively. In SH, they are about $0.33 \mathrm{~K}$ and $0.32 \mathrm{~K}$, respectively. Thus, enhanced warming at $300 \mathrm{hPa}$ is about $0.15 \mathrm{~K}$ greater in $\mathrm{NH}$ than in $\mathrm{SH}$.

To show vertical and latitudinal distribution of tropospheric temperature responses to ozone recovery in more detail, we plot vertical cross-sections of annual and zonal mean temperature trends for the three groups of models in Fig. 5 (Son et al. (2010) showed similar plots for individual CCMVal-1 models, but for the period of 2000-2099). First, these plots show similar spatial trend patterns, with maximum warming all in the tropical upper troposphere which is a common feature in all GCMs (IPCC, 2007). A band of relatively large warming trends extends from the tropical upper troposphere to the NH upper troposphere and to the NH highlatitude surface. Second, Fig. $5 \mathrm{~b}$ and $\mathrm{c}$ all show differences from Fig. 5a. In the stratosphere, both Fig. 5b and c show warming trends in polar regions, especially in the Antarctic, contrasted to the cooling trends in Fig. 5a. It is indicative of the radiative warming effect of ozone recovery in stratospheric polar regions. In the troposphere, warming trends in Fig. $5 b$ and $c$ are all greater than in Fig. 5a. In particular, the band of relatively large warming trends in the tropical and 
(a) 2001-2050

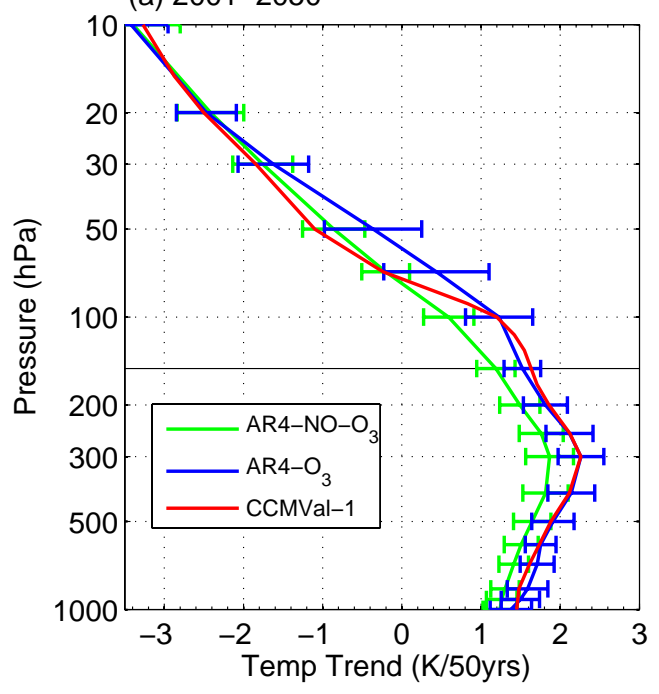

(b) 1965-1999

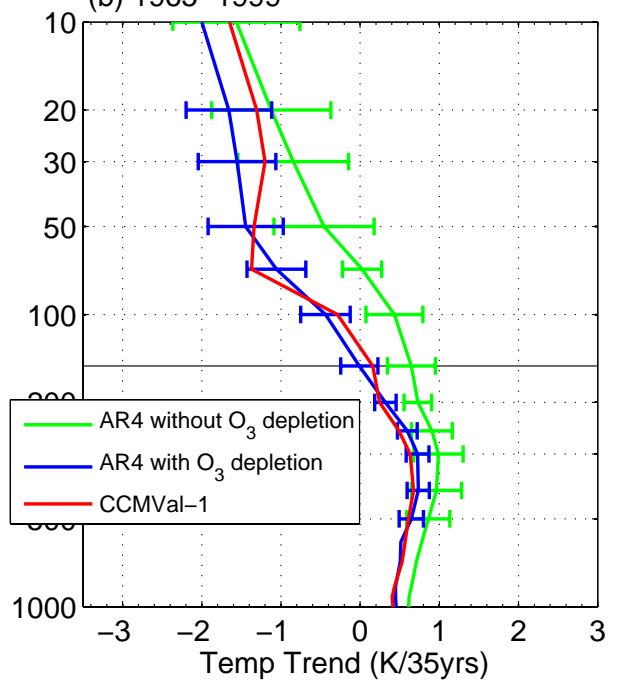

Fig. 2. Vertical profiles of global annual mean temperature trends for each ensemble-mean group for the periods of (a) 2001-2050 and (b) 1965-1999. The error bars indicate one standard deviation only for IPCC models, and error bars for CCMVal-1 models are not plotted. Statistical significance levels of temperature trends at all levels are all higher than the $95 \%$ confidence level, and trend differences among the three groups of models are also statistically significant.

$\mathrm{NH}$ upper troposphere in Fig. 5b and c are greater than that in Fig. 5a. In these plots, trends that have significant levels above the $95 \%$ confidence levels are marked with dots. It is the same for temperature trends and trend differences in the following figures.

Differences of temperature trends between AR4$\mathrm{O}_{3} / \mathrm{CCMVal}-1$ and AR4-NO-O $\mathrm{O}_{3}$ models are plotted in Fig. 6a and b, respectively. Both plots show dominant positive trend differences in the troposphere, indicating enhanced tropospheric warming associated with ozone recovery. They also show similar spatial patterns. That is, enhanced warming is stronger in the middle and upper troposphere than at lower levels, and enhanced warming is stronger in $\mathrm{NH}$ than in SH. In Fig. 6a, the maximum enhanced warming is located in the Arctic upper troposphere, about $0.75 \mathrm{~K}$ over 2010-2050. In Fig. 6b, the maximum enhanced warming is near the Arctic surface, about $1.0 \mathrm{~K}$.

Figure 6a and $\mathrm{b}$ for the stratosphere show both similarity and differences. The similarity is the large enhanced warming in polar regions, especially in the Antarctic lower stratosphere. This is because ozone depletion is more severe in both polar regions than at lower latitudes from the late 1970s to the late 1990s (Solomon, 1999) and ozone recovery implies more ozone increases in the polar stratosphere and, thus, stronger warming. The difference is that Fig. $6 \mathrm{~b}$ shows negative values in the stratosphere, indicating stronger cooling trends in CCMVal-1 models compared with AR4-NO-O models. This was attributed to both a weak decrease in ozone and increased upwelling in the tropical lower stratosphere in CCMVal-1 models (Butchart et al., 2006; Son et al., 2009b).
Enhanced tropospheric warming has seasonal variations. Since both Figs. 2a and 6 indicate that the largest enhanced tropospheric warming is in the upper troposphere, we focus on seasonal variations of temperature trends and their differences at $300 \mathrm{hPa}$. Figure 7 shows latitude-month plots of temperature trends at $300 \mathrm{hPa}$ for the three model groups. The common feature in the three plots is that they all show larger warming trends in the tropics than at higher latitudes and that the larger warming trends extend from the tropics to $\mathrm{NH}$ middle and high latitudes in boreal summer. The differences are that warming trends are generally greater in both AR4-O $\mathrm{O}_{3}$ and CCMVal-1 models than in AR4-NO-O models, and that both AR4- $\mathrm{O}_{3}$ and CCMVal-1 models show larger warming trends at $\mathrm{SH}$ middle and high latitudes in austral summer than in other seasons.

Differences between Fig. 7b and a and between Fig. 7c and a are illustrated in Fig. 8a and b, respectively. First, both plots demonstrate dominant enhanced warming over the globe. Second, both plots show stronger enhanced warming in the extratropics and polar regions in summer and autumn for both hemispheres. The temporal and spatial patterns of enhanced warming in the extratropics and polar regions resemble that of temperature trends (Fig. 7). Trend differences between CCMVal-1 and AR4-NO-O 3 models have two maxima (Fig. 8b). One is located in the NH extratropics in boreal summer, and the another is in the Antarctic in austral summer. The maximum difference in the $\mathrm{NH}$ extratropics in Fig. $8 \mathrm{~b}$ is up to $1.50 \mathrm{~K}$ for the $50 \mathrm{yr}$, and that in the Antarctic is greater than $3.0 \mathrm{~K}$. Note that both maxima in Fig. $8 \mathrm{~b}$ have much greater values compared with that in Fig. 8a, indicating different tropospheric temperature responses to prescribed 


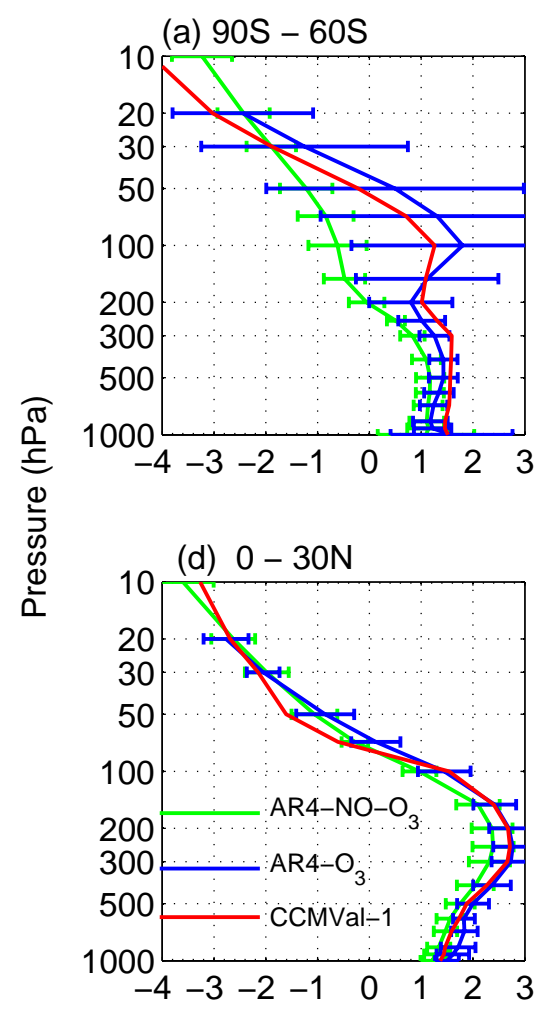

(b) $60 S-30 S$

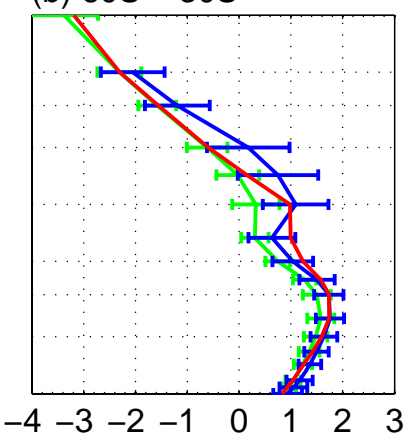

(e) $30 \mathrm{~N}-60 \mathrm{~N}$

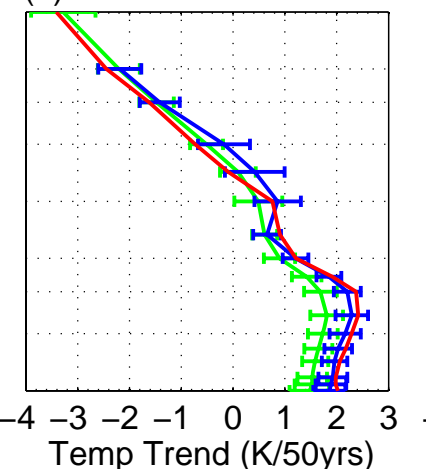

(c) $30 \mathrm{~S}-0$

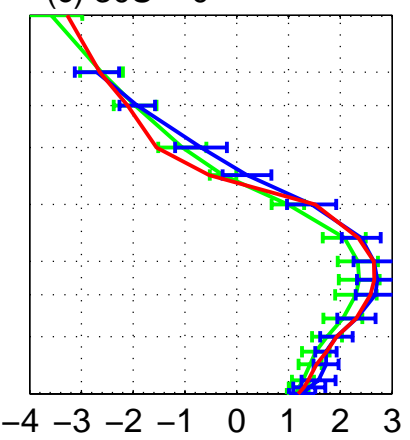

(f) $60 \mathrm{~N}-90 \mathrm{~N}$

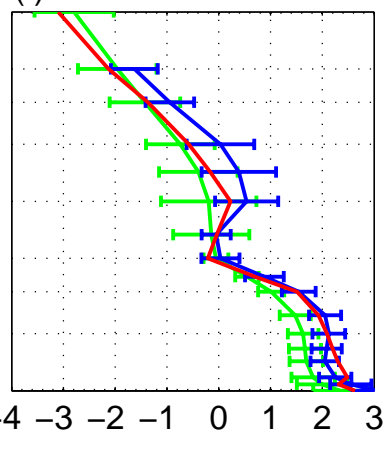

Fig. 3. Same as Fig. 2a, except for annual and regional mean temperature trends. (a) $90^{\circ} \mathrm{S}-60^{\circ} \mathrm{S}$, (b) $60^{\circ} \mathrm{S}-30^{\circ} \mathrm{S}$, (c) $30^{\circ} \mathrm{S}-0$, (d) $0-30^{\circ} \mathrm{N}$, (e) $30^{\circ} \mathrm{N}-60^{\circ} \mathrm{N}$, and (f) $60^{\circ} \mathrm{N}-90^{\circ} \mathrm{N}$.
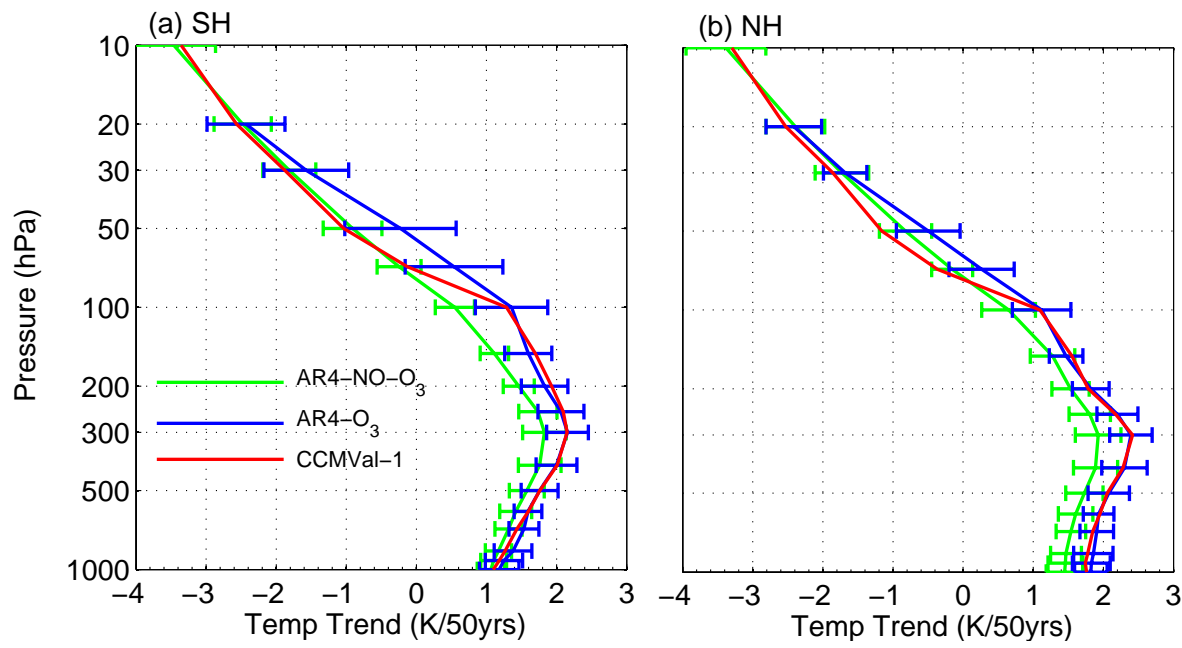

Fig. 4. Same as Fig. 2a, except for annual and hemispheric mean temperature trends. (a) NH and (b) SH.

and interactive ozone recovery. The difference may also be due to that CCMVal-1 models have better resolved stratospheres.

Comparison of seasonal and regional mean temperature trends at $300 \mathrm{hPa}$ are shown in Fig. 9. For all four seasons, as shown above, both $\mathrm{AR}_{4}-\mathrm{O}_{3}$ and CCMVal-1 models produce larger warming trends than AR4-NO-O $\mathrm{O}_{3}$ models do. For March-April-May (MAM) and September-OctoberNovember (SON) (Fig. 9a and c), warming trends in AR4$\mathrm{O}_{3}$ and CCMVal-1 models are comparable at all latitudes in general, and they all show larger differences from the trends in AR4-NO-O $\mathrm{O}_{3}$ models in $\mathrm{NH}$ than in $\mathrm{SH}$. For boreal summer (Fig. 9b), CCMVal-1 models yield the largest warming trend at $\mathrm{NH}$ middle latitudes, about $3.1 \mathrm{~K}$ for the $50 \mathrm{yr}$, while 
(a)

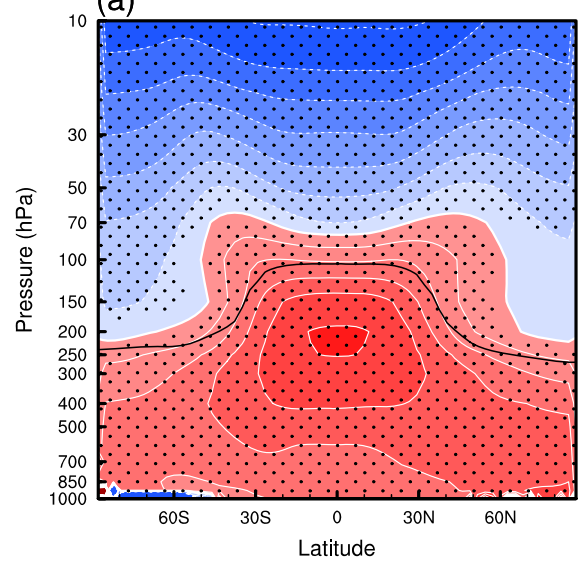

(b)

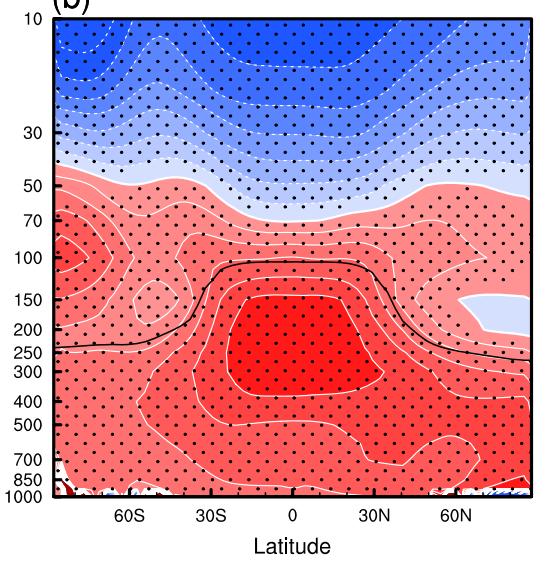

(c)

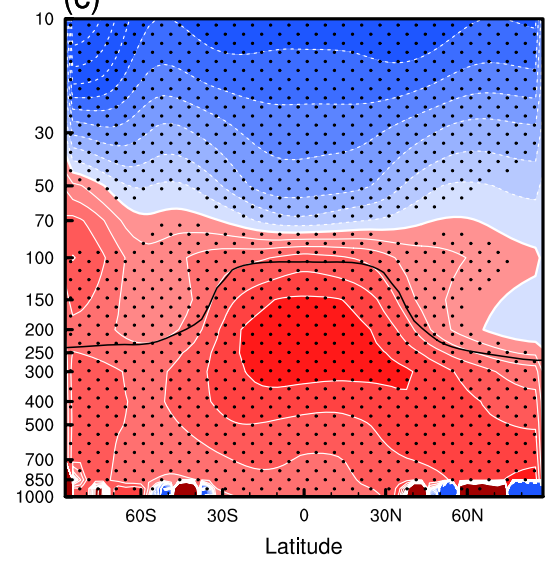

$-3$

$-2$

$-1$

0

1

2

3

Fig. 5. Annual and zonal mean temperature trends over 2001-2050 for (a) AR4-O $\mathrm{O}_{3}$, (b) AR4-NO-O 3 and (c) CCMVal-1-1 models. Colour interval is $0.5 \mathrm{~K}$ per 50 years, pink: positive, and blue: negative. Black lines in the plots indicate the climatological positions of the tropopause. Regions with dots are the places where trend differences have statistical significant levels higher than the $95 \%$ confidence level (student t-test values are greater than 2.0). In the following figures, dots have the same indication of statistical significance for temperature trends and trend differences.

(a)

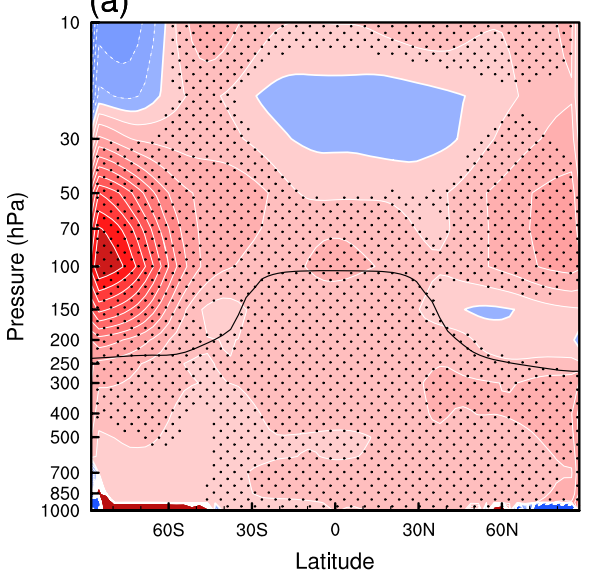

(b)

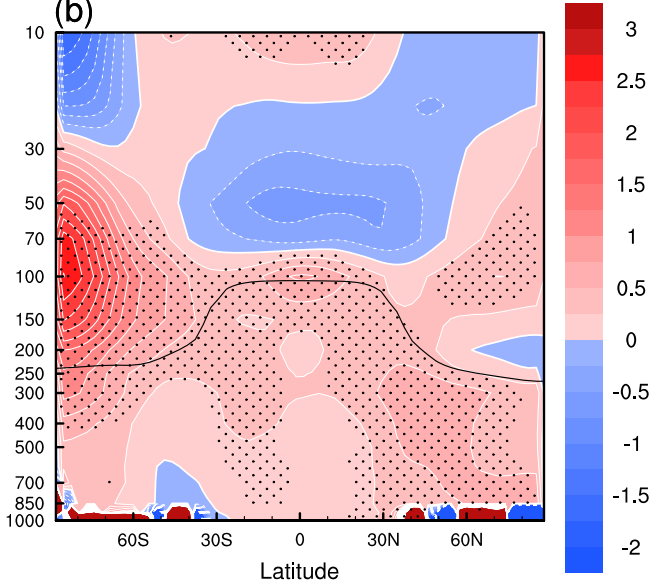

Fig. 6. Differences of annual and zonal mean temperature trends over 2001-2050 (a) between AR4- $\mathrm{O}_{3}$ and AR4-NO-O 3 models, and (b) between CCMVal-1 and AR4-NO-O 3 models. Colour interval is $0.25 \mathrm{~K}$ per $50 \mathrm{yr}$, pink: positive, and blue: negative. Black lines in the plots indicate the climatological position of the tropopause.

in $\mathrm{SH}$ warming trends are larger in $\mathrm{AR} 4-\mathrm{O}_{3}$ models than in CCMVal-1 models. For austral summer (Fig. 9d), warming trends are larger in CCMVal- 1 models than in $\mathrm{AR} 4-\mathrm{O}_{3}$ models at all latitudes. Especially in the Antarctic, the largest warming trend in CCMVal- 1 models is about $3.0 \mathrm{~K}$ over the $50 \mathrm{yr}$, nearly double of the warming trend in $\mathrm{AR} 4-\mathrm{O}_{3}$ models.

Near-surface air temperatures also demonstrate enhanced warming associated with ozone recovery, which can be seen in Figs. 1-3. To show near-surface air temperature responses to ozone recovery, we calculate surface air temper- ature (SAT) trends for the two groups of AR4 models and their differences (CCMVal-1 models have no available SAT output). Figure 10a and $\mathrm{b}$ show latitude-month plots of SAT trends from AR4-NO-O 3 and AR4-O 3 models, respectively. Both groups of models display dominant global warming trends. They also show similar seasonal-spatial patterns of SAT trends. That is, warming trends are greater in $\mathrm{NH}$ than in $\mathrm{SH}$, and stronger warming trends are in polar regions in winter than in other regions for both hemispheres, especially in the Arctic in boreal winter. Overall, the SAT trends in 
(a)

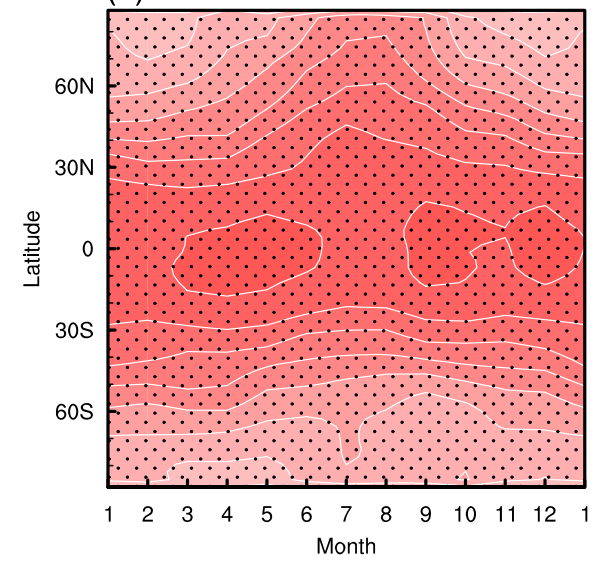

(b)

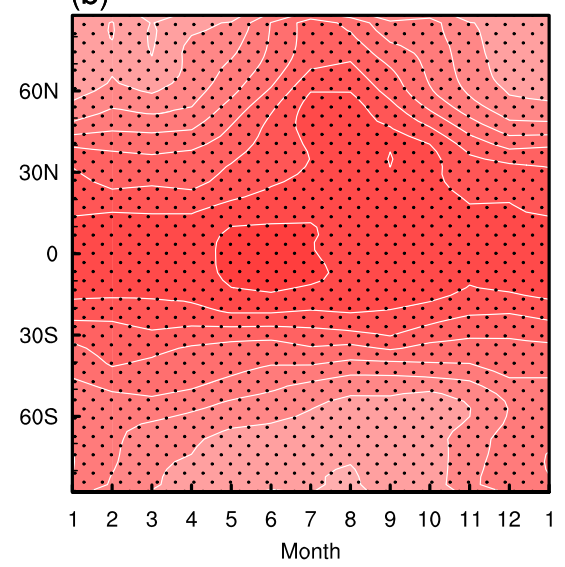

(c)

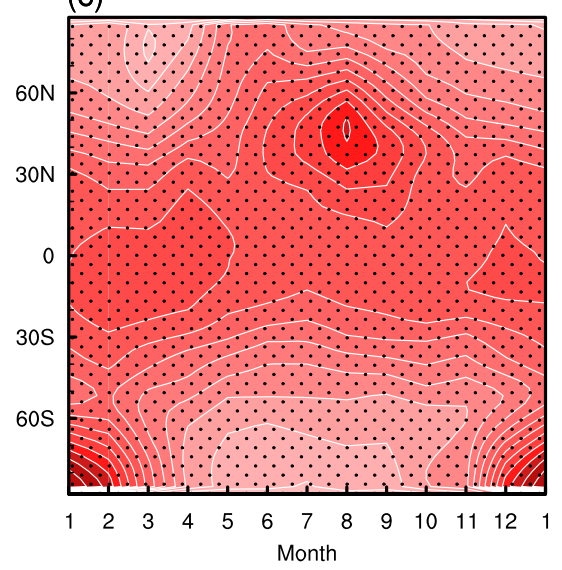

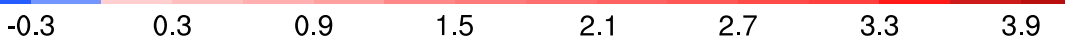

Fig. 7. Latitude-month plots of zonal-mean temperature trends at $300 \mathrm{hPa}$ over 2001-2050. (a) AR4-NO-O 3 , (b) AR4- $\mathrm{O}_{3}$ and (c) CCMVal-1 models. Colour interval is $0.30 \mathrm{~K}$ per $50 \mathrm{yr}$.
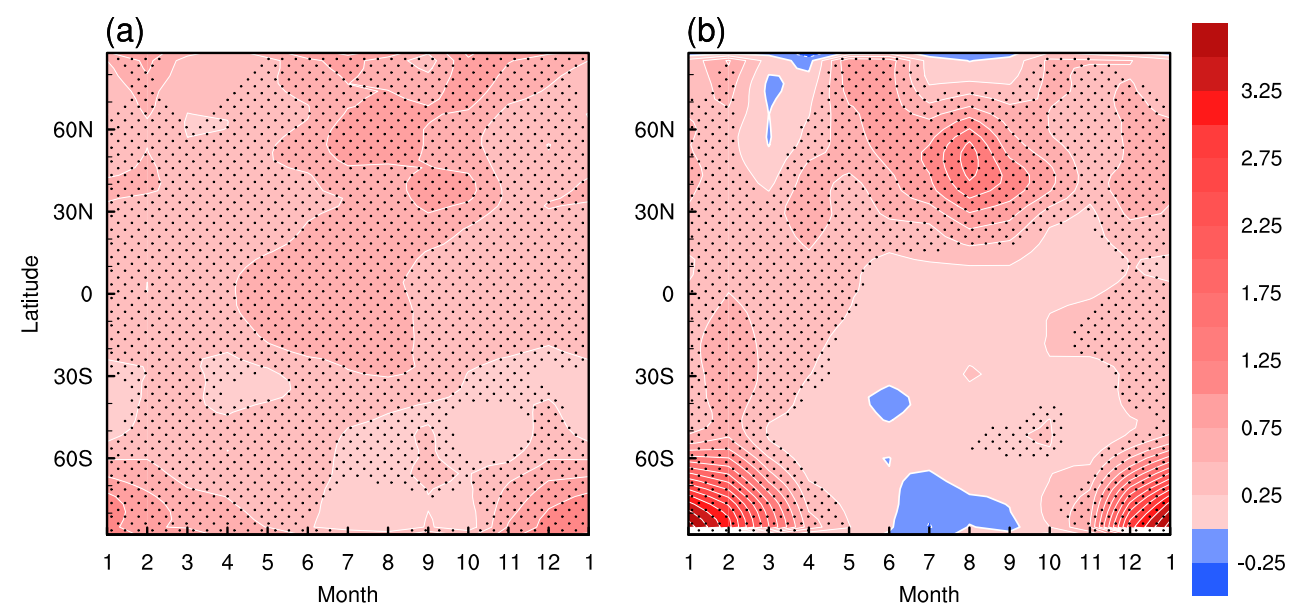

Fig. 8. Latitude-month plots of zonal-mean temperature trend differences at $300 \mathrm{hPa}$ over 2001-2050. (a) Difference between AR4- $\mathrm{O}_{3}$ and AR4-NO-O $\mathrm{O}_{3}$ models, and (b) difference between CCMVal- 1 and AR4-NO-O $\mathrm{O}_{3}$ models. Colour interval is $0.25 \mathrm{~K}$ per 50 years, pink: positive, and blue: negative.

AR4- $\mathrm{O}_{3}$ models are generally greater than in AR4-NO-O 3 models.

Trend differences between $\mathrm{AR} 4-\mathrm{O}_{3}$ and AR4-NO-O models are shown in Fig. 11. Enhanced warming is dominant, except for the austral winter and spring over Antarctic. Maximum enhanced warming is found in the Arctic in boreal autumn and winter. At $\mathrm{NH}$ middle latitudes, large enhanced warming occurs in boreal summer. In SH, trend differences in the tropics and extratropics have no seasonal variations. Again, the temporal and spatial patterns of trend differences resemble that of SAT trends (Fig. 10), both indicating the polar amplification in the Arctic due to the icealbedo feedback (IPCC, 2007). It is worth pointing out that the negative differences in the Antarctic in austral winter and spring are mainly due to weaker warming over the western Antarctic, including the Antarctic Peninsula, in AR4$\mathrm{O}_{3}$ models. This is contrasted to observed SAT warming over the same region for the period of 1969-2000 (Thompson and Solomon, 2002), which was suggested as a result of ozone depletion in the Antarctic stratosphere (Thompson and Solomon, 2002; Gillett and Thompson, 2003). Therefore, the contrast suggests that ozone recovery may dominate and offset greenhouse warming over the western Antarctic (Perlwitz et al., 2008). The global and annual average of enhanced SAT warming is about $0.16 \mathrm{~K}$ over $2001-2050$. The enhanced SAT warming has large asymmetry between 

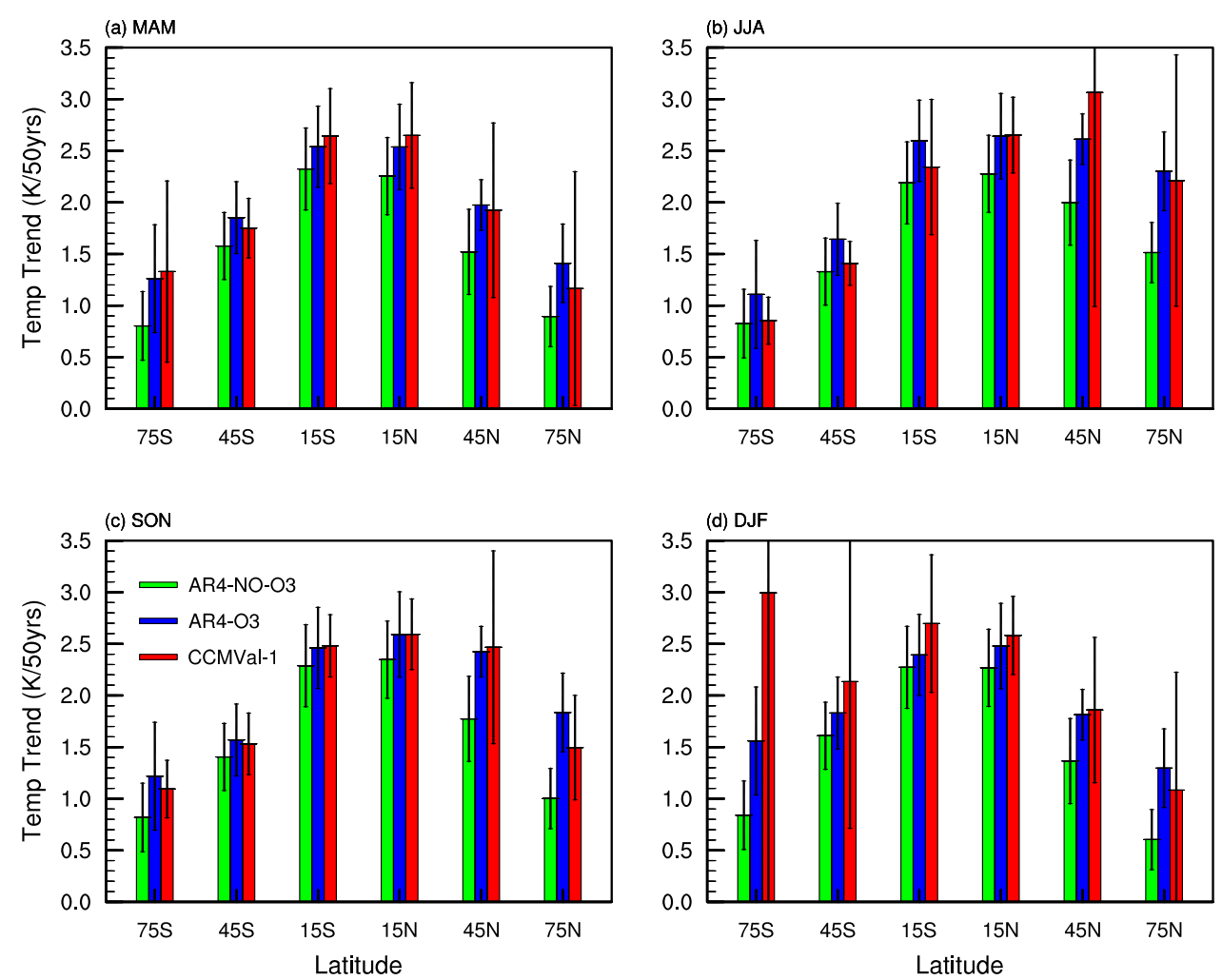

Fig. 9. Comparison of zonal-mean temperature trends at $300 \mathrm{hPa}$ by latitude over 2001-2050. (a) MAM, (b) JJA, (c) SON and (d) DJF.
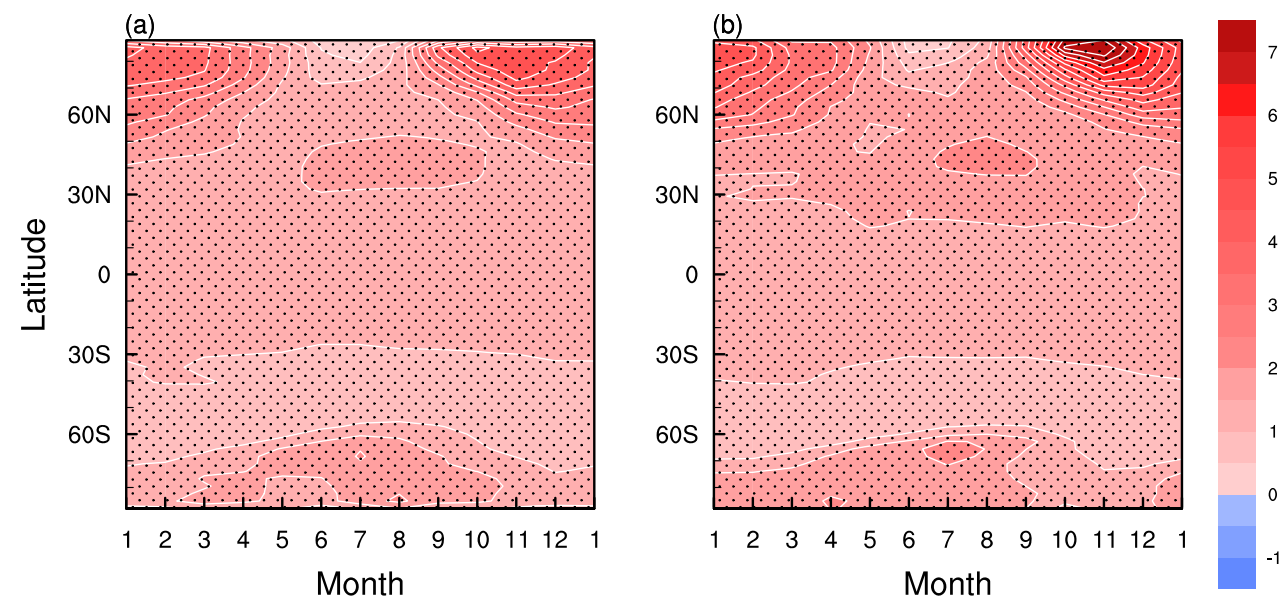

Fig. 10. Latitude-month plots of zonal-mean SAT trends for AR4 models. (a) AR4-NO-O 3 models and (b) AR4-O $\mathrm{O}_{3}$ models. Colour interval is $0.50 \mathrm{~K}$ per 50 years, pink: positive, and blue: negative.

the two hemispheres. The annual and hemispheric enhanced warming is $0.35 \mathrm{~K}$ in $\mathrm{NH}$ and $0.11 \mathrm{~K}$ in $\mathrm{SH}$ for the $50 \mathrm{yr}$.

To confirm the above GCM results, we calculate troposphere-surface temperature responses to ozone changes between 2001 and 2050, using a radiative-convective model. Vertical profiles of global and annual mean ozone volume mixing ratios for 2001 and 2050 are from ensemble averages of CCMVal-1 models. Instead of using the actual ozone values of these two years from the model, we first make linear regression for ozone volume mixing ratios at all levels, and then the linearly regressed ozone values for 2001 and 2050 are used. All other atmospheric compositions are the same as in the US Standard Atmosphere. The fixed relative humidity is applied to consider the water vapour feedback (Manabe 


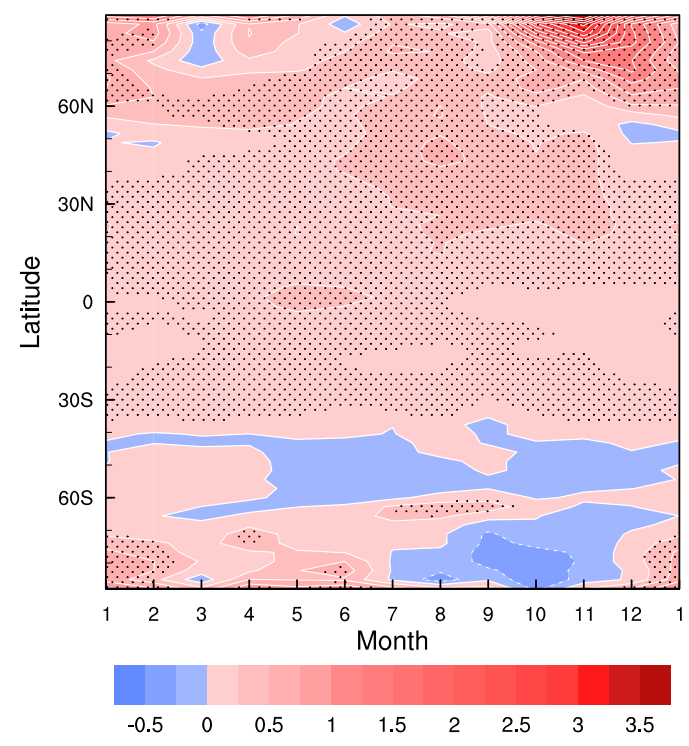

Fig. 11. Latitude-month plots of zonal-mean SAT trend differences between AR4-O 3 and AR4-NO-O 3 models over 2001-2050. Colour interval is $0.25 \mathrm{~K}$ per $50 \mathrm{yr}$, pink: positive, and blue: negative.

and Wetherald, 1967), with a surface relative humidity of $80 \%$. Temperature lapse rate is set to be $6.5 \mathrm{~K} \mathrm{~km}^{-1}$. The solar zenith angle is 60 degrees, the length of daytime is $12 \mathrm{~h}$ and the surface albedo is 0.2 . The simulated surface temperature is $288 \mathrm{~K}$ for the standard atmosphere, close to the global and annual mean surface temperature at present.

Figure 12a shows the simulated vertical profile of temperature differences between 2050 and 2001. The middle and upper stratosphere shows positive trends, with the largest positive difference of about $2.4 \mathrm{~K}$ at about $1.5 \mathrm{hPa}$, while the lower stratosphere has weak negative values between about 70 and $15 \mathrm{hPa}$, with a magnitude of about $-0.15 \mathrm{~K}$. The negative trend is consistent with that in Fig. 6b, which also shows negative trends in the lower stratosphere. Temperature changes in the troposphere are all positive, indicating increasing troposphere-surface temperatures by ozone recovery. To show tropospheric temperature changes more clearly, the part enclosed by the box is enlarged and shown in Fig. 12b. Temperature changes above $250 \mathrm{hPa}$ are a result of radiative equilibrium because convective adjustment can only reach $250 \mathrm{hPa}$. Therefore, the peak of temperature increase between 250 and $100 \mathrm{hPa}$ is due to a relatively large increase of ozone in that layer. Temperature increase below $250 \mathrm{hPa}$ is about $0.1 \mathrm{~K}$. The almost uniform distribution throughout is because temperature lapse rate is the same at all levels, i.e., $6.5 \mathrm{~K} \mathrm{~km}^{-1}$.

The increase of troposphere-surface temperature from the radiative-convective model confirms that stratospheric ozone recovery will lead to enhanced troposphere-surface warming. But the increase in troposphere-surface temperature from the radiative-convective model is smaller than that in GCMs.
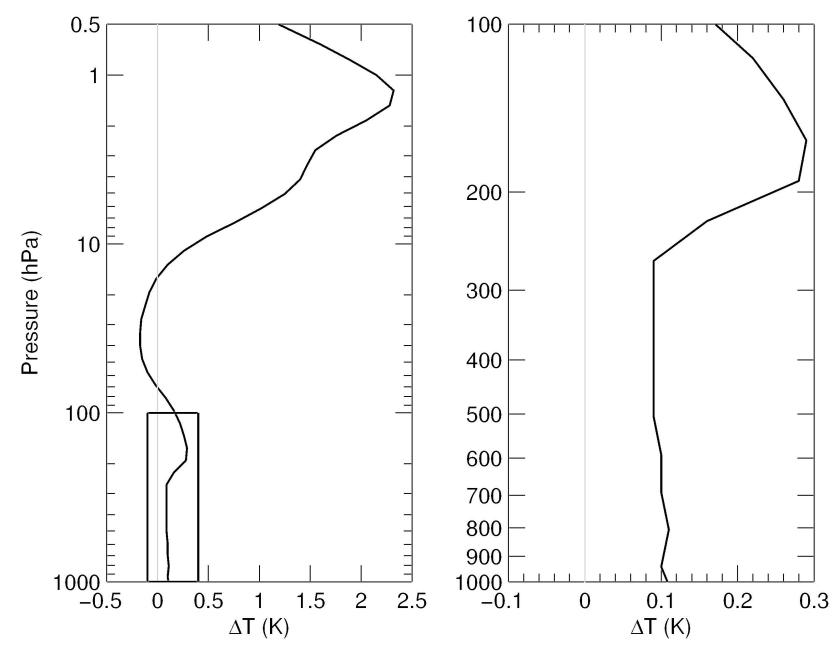

Fig. 12. Temperature changes between 2001 and 2050, calculated from a radiative-convective model. Panel (b) is zoomed on the box in panel (a).

There are several possible reasons for the weaker warming. First, the radiative-convective model has no clouds, which absorbs radiation at $9.6 \mu \mathrm{m}$. Second, it has no ice-albedo feedback on the surface. Third, it has a fixed temperature lapse rate, rather than self-adjusted temperature lapse rate in GCMs.

\section{Discussion and conclusions}

By comparing multimodel ensemble simulation results, we have demonstrated that tropospheric and surface temperatures have robust responses to stratospheric ozone recovery in the first half of the 21st century. Both AR4 models with prescribed ozone recovery and coupled chemistry-climate models with projected reduction of atmospheric chlorine loading all predict highly consistent and statistically significant enhanced warming of tropospheric and surface temperatures as compared with AR4 models without ozone recovery. For global and annual average, the maximum enhanced warming is located in the upper troposphere, with a value of about $0.41 \mathrm{~K}$ for the period of 2001-2050, and enhanced SAT warming is about $0.16 \mathrm{~K}$. The enhanced tropospheric warming displays asymmetry between the two hemispheres. Both AR4 models with ozone recovery and CCMVal-1 models yield stronger enhanced tropospheric warming in $\mathrm{NH}$ than in $\mathrm{SH}$, about $0.48 \mathrm{~K}$ versus about $0.33 \mathrm{~K}$ at $300 \mathrm{hPa}$ for the $50 \mathrm{yr}$. The enhanced SAT warming is about $0.35 \mathrm{~K}$ in NH, contrasted to $0.11 \mathrm{~K}$ in $\mathrm{SH}$. Enhanced tropospheric and surface warming also shows seasonal and latitudinal variations. In the upper troposphere, relatively large enhanced warming occurs in polar regions and middle latitudes in summer for both hemispheres. On the surface, relatively large enhanced warming occurs in polar regions in winter for both 
hemispheres. The results here suggest that ozone recovery will cause a positive radiative forcing on tropospheric and surface climate in the 21st century. The positive forcing is confirmed by results from the radiative-convective model, which show about $0.1 \mathrm{~K}$ increase with ozone forcing derived from CCMVal-1 models.

Enhanced warming shows robust spatial-temporal patterns that resemble the patterns of temperature trends. That is, relatively large enhanced warming occurs in the places where warming trends are also relatively large in general, such as the tropical upper troposphere and the Arctic winter surface. The resemblance of spatial-temporal patterns between enhanced warming and temperature trends also indicates that the enhanced warming is not due to model performance. The spatial-temporal patterns of enhanced warming also indicate that the enhanced warming is not purely a result of the radiative effect of ozone recovery, but involves dynamical and feedback processes. It is well known that the stronger warming trends in the tropical upper troposphere than in other tropospheric regions in AR4 simulations are a result of the lapse-rate and water-vapour feedback (IPCC, 2007). Therefore, the relatively large enhanced warming in the tropical upper troposphere is also associated with the lapse-rate and water-vapour feedback. It is also well known that the icealbedo feedback is an important reason for causing stronger Arctic surface warming than in other regions. Thus, the relatively large enhanced SAT warming on the Arctic surface is associated with the positive ice-albedo feedback.

The non-uniform enhancement of tropospheric warming may alter tropospheric circulations and regional and global climate. The greater enhancement at middle and high latitudes in summer for both hemispheres indicates weakened latitudinal temperature gradients and, thus, decelerated westerly winds and weakened baroclinic wave activity in the extratropics. In particular, enhanced tropospheric warming in polar regions would lead to reversed polarity of trends in the annular mode (Perlwitz et al., 2008; Son et al., 2008, 2009a, 2010). Tropospheric circulation changes might consequently lead to changes in stratospheric circulations and climate. For example, decelerated extratropical westerly winds enhance upward planetary-wave propagation from the troposphere into the stratosphere and cause weakened stratospheric polar vortices in winter. The enhanced SAT warming, especially the relatively large enhancement in the Arctic autumn and winter, may accelerate sea-ice melting in the Arctic Ocean.

Note that the results reported here are based on multimodel ensemble averages. As mentioned before, prescribed ozone recovery in AR4 models is not well documented. More importantly, other forcings such as black carbon and volcanic eruptions may not be included in all AR4 models: the AR4 models that consider the ozone recovery also include more complete forcings, which may contribute to the enhanced warming. Thus, to fully quantify tropospheric and surface temperature responses to stratospheric ozone recovery, it is important to run an individual coupled GCM with and with- out ozone recovery for all other forcings in future studies. In addition, although CCMVal-1 models show great consistency with $\mathrm{AR} 4-\mathrm{O}_{3}$ models and provide a good complement with interactive ozone chemistry and better resolved stratospheric dynamics, one problem is that CCMVal-1 models used prescribed SSTs from AR4-O ${ }_{3}$ models. Prescribed SSTs from AR4 models may partly or largely damp tropospheric and surface temperature responses to the radiative forcing of ozone recovery in CCMVal-1 models. This is because the mean vertical temperature profiles in the troposphere, especially in the tropical troposphere, largely follow the moist adiabatic profile, as a consequence of radiativeconvective equilibrium. Thus, the temperature profile is well constrained by the surface temperature and the lapse rate, and changes in tropospheric temperatures in CCMVal-1 models are primarily responsive to prescribed SSTs. Therefore, coupled atmospheric-oceanic CCM simulations are necessary for verifying tropospheric and surface temperature responses to stratospheric ozone recovery.

The results here are based on the moderate emission scenario of greenhouse gases (A1B scenario). High emission scenarios of greenhouse gases, such as A2 scenario, will lead to stronger stratospheric cooling, which would consequently cause greater increases in stratospheric ozone (WMO, 2007) or even supper-ozone recovery (Chipperfield, 2009). In that case, the enhanced troposphere-surface warming would be even greater.

Acknowledgements. We acknowledge the modelling groups, the Programme for Climate Model Diagnosis and Intercomparison (PCMDI) and the WCRP Working Group on Coupled Modelling (WGCM) for their roles in making available the WCRP CMIP3 multi-model dataset. Support of this dataset is provided by the Office of Science, US Department of Energy. We thank the World Climate Research Programme SPARC CCMVal-1 project for organizing the chemistry-climate model (CCM) data analysis activity, the British Atmospheric Data Center for collecting and archiving the CCM output. Y. Hu and Y. Xia are supported by the National Basic Research Programme of China (973 Programme, 2010CB428606) and by NSF of China under grant 40875042 and 41025018. Q. Fu is in part supported by NOAA Grant NA08OAR4310725 and the National Basic Research Program of China (2010CB428604).

Edited by: M. Van Roozendael

\section{References}

Butchart, N., Scaife, A. A., Bourqui, M., de Grandpre, J., Hare, S. H. E., Kettleborough, J., Langematz, U., Manzini, E., Sassi, F., Shibata, K., Shindell, D., and Sigmond, M.: Simulations of anthropogenic change in the strength of the Brewer-Dobson circulation, Clim. Dyn., 27, 727-741, 2006.

Chen, G. and Held, I. M.: Phase speed spectra and the recent poleward shift of Southern Hemisphere surface westerlies, Geophys. Res. Lett., 34, L21805, doi:10.1029/2007GL031200, 2007. 
Chipperfield, M.: Nitrous oxide delays ozone recovery, Nature Geosci., 2, 742-743, 2009.

Cordero, E. C. and Forster, P. M. de F.: Stratospheric variability and trends in models used for the IPCC AR4, Atmos. Chem. Phys., 6, 5369-5380, doi:10.5194/acp-6-5369-2006, 2006.

Eyring, V., Butchart, N., Waugh, D. W., Akiyoshi, H., Austin, J., Bekki, S., Bodeker, G. E., Boville, B. A., Brühl, C., Chipperfield, M. P., Cordero, E., Dameris, M., Deushi, M., Fioletov, V. E., Frith, S. M., Garcia, R. R., Gettelman, A., Giorgetta, M. A., Grewe, V., Jourdain, L., Kinnison, D. E., Mancini, E., Manzini, E., Marchand, M., Marsh, D. R., Nagashima T., Newman, P. A., Nielsen, J. E., Pawson, S., Pitari, G., Plummer, D. A., Rozanov, E., Schraner, M., Shepherd, T. G., Shibata, K., Stolarski, R. S., Struthers, H., Tian, W., and Yoshiki, M.: Assessment of temperature, trace species, and ozone in chemistry-climate model simulations of the recent past, J. Geophys. Res., 111, D22308, doi:10.1029/2006JD007327, 2006.

Eyring, V., Waugh, D. W., Bodeker, G. E., Cordero, E., Akiyoshi, H., Austin, J., Beagley, S. R., Boville, B. A., Braesicke, P., Brühl, C., Butchart, N., Chipperfield, M. P., Dameris, M., Deckert, R., Deushi, M., Frith, S. M., Garcia, R. R., Gettelman, A., Giorgetta, M. A., Kinnison, D. E., Mancini, E., Manzini, E., Marsh, D. R., Matthes, S., Nagashima, T., Newman, P. A., Nielsen, J. E., Pawson, S., Pitari, G., Plummer, D. A., Rozanov, E., Schraner, M., Scinocca, J. F., Semeniuk, K., Shepherd, T. G., Shibata, K., Steil, B., Stolarski, R. S., Tian, W., and Yoshiki, M.: Multimodel projections of stratospheric ozone in the 21st century, J. Geophys. Res., 112, D16303, doi:10.1029/2006JD008332, 2007.

Forster, P. M. de F. and Shine, K. P.: Radiative forcing and temperature trends from stratospheric ozone change, J. Geophys. Res., 102, 10841-10855, 1997

Fu, Q., Johanson, C. M., Wallace, J. M., and Reichler, T.: Enhanced mid-latitude tropospheric warming in satellite measurements, Science, 312, 1179, doi:10.1126/science.1125566, 2006.

Gillett, N. P. and Thompson, D. W. J.: Simulation of recent Southern Hemisphere climate change, Science, 302, 273-275, 2003.

Hartmann, D. L., Wallace, J. M., Limpasuvan, V., Thompson, D. W. J., and Holton, J. R.: Can ozone depletion and global warming interact to produce rapid climate change?, P. Natl. Acad. Sci., 97, 1412-1417, 2000.

$\mathrm{Hu}, \mathrm{Y}$. and $\mathrm{Fu}, \mathrm{Q} .:$ Observed poleward expansion of the Hadley circulation since 1979, Atmos. Chem. Phys., 7, 5229-5236, doi:10.5194/acp-7-5229-2007, 2007.

$\mathrm{Hu}, \mathrm{Y}$. and Tung, K.-K.: Possible ozone induced long-term change in planetary wave activity in late winter, J. Climate, 16, 3027$3038,2003$.

Hu Y., Tung, K.-K., and Liu, J.: A closer comparison of early and late winter atmospheric trends in the Northern-Hemisphere, J. Climate, 18, 2924-2936, 2005.

IPCC: Climate Change 2007: The Physical Science Basis. Contribution of Working Group I to the Fourth Assessment Report of the Intergovernmental Panel on Climate Changes, edited by: Solomon, S., Qin, D., Manning, M., Marquis, M., Averyt, K., Tignor, M. M. B., Miller, H. L., and Chen, Z., Cambridge University Press, Cambridge, UK, 996 pp., 2007.

Lacis, A. A, Wuebbles, D. J., and Logan, J. A.: Radlatlve forclng of climate by changes in the vertical distrihurion nf ozone, J. Geophys. Res., 95, 9971-9981, 1990.

Manabe, S. and Wetherald, R. T.: Thermal equilibrium of the atmo- sphere with a given distribution of relative humidity, J. Atmos. Sci., 24, 241-259, 1967.

Meehl, G. A., Stocker, T. F., Collins, W. D., Friedlingstein, P., Gaye, A. T., Gregory, J. M., Kitoh, A., Knutti, R., Murphy, J. M., Noda, A., Raper, S. C. B., Watterson, I. G., Weaver, A. J., and Zhao Z.-C.: Climate Change 2007: The Physical Science Basis. Contribution of Working Group I to the Fourth Assessment Report of the Intergovernmental Panel on Climate Change (Cambridge Univ. Press, Cambridge), 747-845, 2007.

Molnar, G. I., Ko, M. K. W., Zhou, S., and Sze, N. D.: Climatic consequences of observed ozone loss in the 1980s: Relevance to the greenhouse problem, J. Geophys. Res., 99, 25755-25760, 1994.

Pavlov, A. A., Kasting, J. F., Brown, L. L., Rages, K. A., and Freedman, R.: Greenhouse warming by $\mathrm{CH} 4$ in the atmosphere of early Earth, J. Geophys. Res., 105, 11981-11990, 2000.

Perlwitz, J., Pawson, S., Fogt, R., Nielsen, J. E., and Neff, W.: The impact of stratospheric ozone hole recovery on Antarctic climate, Geophys. Res. Lett., 35, L08714, doi:10.1029/2008GL033317, 2008.

Polvani, L. M., Waugh, D. W., Correa, G. J. P., and Son, S.-W.: Stratospheric ozone depletion: the main driver of 20th Century atmospheric circulation changes in the Southern Hemisphere, J. Climate, 24, 795-812, doi:10.1175/2010JCLI3772.1, 2010.

Ramanathan, V. and Dickinson, R. E.: The role of stratospheric ozone in the zonal and seasonal radiative energy balance of the earth-troposphere system, J. Atmos. Sci., 36, 1084-1104, 1979.

Ramaswamy, V., Schwarzkopf, M. D., and Shine, K. P.: Radiative forcing of climate from halocarbon-induced stratospheric ozone loss, Nature, 155, 810-812, 1992.

Seidel, D. J., Fu, Q., Randel, W. J., and Reichler, T. J.: Widening of the tropical belt in a changing climate, Nature Geosci., 1, 21-24, 2008

Solomon, S.: Stratospheric ozone depletion: a review of concepts and history, Rev. Geophys., 37, 275-316, 1999.

Son, S.-W., Polvani, L. M., Waugh, D. W., Akiyoshi, H., Garcia, R., Kinnison, D., Pawson, S., Rozanov, E., Shepherd, T. G., and Shibata, K.: The Impact of Stratospheric Ozone Recovery on the Southern Hemisphere Westerly Jet, Science, 320, 1486-1489, 2008.

Son, S.-W., Tandon, N. F., Polvani, L. M., and Waugh, D. W.: Ozone hole and Southern Hemisphere climate change, Geophys. Res. Lett., 36, L15705, doi:10.1029/2009GL038671, 2009a.

Son, S.-W., Polvani, L. M., Waugh, D. W., Birner, T., Akiyoshi, H., Garcia, R., Gettelman, A., Plummer, D. A., and Rozanov, E.: The impact of stratospheric ozone recovery on tropopause height trends, J. Climate, 22, 429-445, 2009b.

Son, S.-W., Gerber, E. P., Perlwitz, J., Polvani, L. M., Gillett, N. P., Seo, K.-H., Eyring, V., Shepherd, T. G., Waugh, D., Akiyoshi, H., Austin, J., Baumgaertner, A., Bekki, S., Braesicke, P., Brühl, C., Butchart, N., Chipperfield, M. P., Cugnet, D., Dameris, M., Dhomse, S., Frith, S., Garny, H., Garcia, R., Hardiman, S. C., Jöckel, P., Lamarque, J. F., Mancini, E., Marchand, M., Michou, M., Nakamura, T., Morgenstern, O., Pitari, G., Plummer, D. A., Pyle, J., Rozanov, E., Scinocca, J. F., Shibata, K., Smale, D., Teyssdre, H., Tian, W., and Yamashita Y.: The impact of stratospheric ozone on the southern hemisphere circulation changes: A multimodel assessment, J. Geophys. Res., 115, D00M07, doi:10.1029/2010JD014271, 2010. 
Thompson, D. W. J. and Solomon, S.: Interpretation of recent Southern Hemisphere climate change, Science, 296, 895-899, 2002.

Thompson, D. W. J. and Wallace, J. M.: Regional climate impacts of the Northern Hemisphere annular mode, Science, 293, 85-89, 2001.

Velders, G. J. M., Andersen, S. O., Daniel J. S., Fahey D. W., and McFarland, M.: The importance of the Montreal Protocol in protecting climate, P. Natl. Acad. Sci., 104, 4814-4819, doi:10.1073/pnas.0610328104, 2007.

Wang, W.-C., Pinto, J. P., and Yung, Y. L.: Climatic effects due to Halogenated compounds in the Earth's atmosphere, J. Atmos. Sci., 337, 333-338, 1980.
Wang, W.-C., Zhuang, Y. C., and Uojkov, R. D.: Climate implications of observed changes in ozone vertical distributions at middle and high latitudes of the northem hemisphere, Geophys. Res. Lett., 20(15), 1567-1570, 67170, doi:10.1029/93GL01318, 1993.

Weatherhead, E. C. and Andersen, S. B.: The search for signs of recovery of the ozone layer, Nature, 441, 39-45, 2006.

WMO (World Meteorological Organization): Scientific Assessment of Ozone Depletion: 2006, WMO Global Ozone Research and Monitoring Project Rep. 50, Geneva, Switzerland, 572 pp., 2007. 